\title{
QUALITY OF LIFE, SEXUAL SATISFACTION AND PSYCHIATRIC CO-MORBIDITY IN WOMEN POSTED FOR HYSTERECTOMY
}

\author{
Vidhyavathi Malyam¹, Sumanth Tarikere Parameshwaraiah2, Vishnuvardhan Gopalkrishna ${ }^{3}$, Asha Chandahalli Sannappa ${ }^{4}$, \\ Vinoda Kumar ${ }^{5}$ \\ ${ }^{1}$ Assistant Professor, Department of Psychiatry, Rajarajeshwari Medical College and Hospital, Bangalore, Karnataka, India. \\ ${ }^{2}$ Assistant Professor, Department of Psychiatry, Rajarajeshwari Medical College and Hospital, Bangalore, Karnataka, India. \\ 3Professor, Department of Psychiatry, Rajarajeshwari Medical College and Hospital, Bangalore, Karnataka, India. \\ ${ }^{4}$ Senior Resident, Department of Psychiatry, Rajarajeshwari Medical College and Hospital, Bangalore, Karnataka, India. \\ ${ }^{5}$ Senior Resident, Department of Psychiatry, Rajarajeshwari Medical College and Hospital, Bangalore, Karnataka, India.
}

\begin{tabular}{l}
\hline ABSTRACT \\
BACKGROUND \\
Uterus holds a deeply symbolic meaning to women. Its removal can have a significant effect on one's quality of life, sexual \\
functioning and psychological well-being. \\
Aims and Objectives- To evaluate the quality of life, sexual satisfaction and psychiatric co-morbidity in women posted for \\
hysterectomy.
\end{tabular}

\section{MATERIALS AND METHODS}

30 subjects aged between 18 and 50 years were taken for convenience, posted for hysterectomy, were evaluated using a semistructured socio-demographic proforma, World Health Organisation Quality of Life- BREF, sexual satisfaction scale for women and clinical version of Structured Clinical Interview DSM-IV before surgery.

Statistical analysis used- Parameters were assessed using correlation coefficient and Mann-Whitney U-test and the p-value of $<0.05$ was considered significant.

Setting and Design- Study was conducted in a tertiary care hospital. A cross-sectional study design was used.

\section{RESULTS}

Subjects with low income and who were literates showed statistically significant psychological problems. Quality of life of those with low income was also significantly affected in environmental domain.

\section{CONCLUSION}

High prevalence of psychiatric co-morbidity, decreased sexual satisfaction and quality of life pre-operatively in women posted for hysterectomy suggests the need for better awareness among treating professionals and need for adequate psychological support for them.

\section{KEY WORDS}

Hysterectomy, Quality of Life (QOL), Sexual Satisfaction, Psychiatric Co-morbidity.

HOW TO CITE THIS ARTICLE: Malyam V, Parameshwaraiah ST, Gopalkrishna V, et al. Quality of life, sexual satisfaction and psychiatric co-morbidity in women posted for hysterectomy. J. Evolution Med. Dent. Sci. 2018;7(26):2989-2993, DOI: $10.14260 /$ jemds $/ 2018 / 673$

\section{BACKGROUND}

The uterus is a major female reproductive organ in mammals including humans. Historically, uterus has been regarded as the regulator and controller of important physiological functions, as a sexual organ, a source of energy, strength, vitality as well as a maintainer of youth and attractiveness among women. Thus, it influences the quality of life [QOL] and sexual functioning, and its loss is known to cause psychiatric morbidity. ${ }^{1-3}$

'Financial or Other Competing Interest': None.

Submission 24-05-2018, Peer Review 12-06-2018,

Acceptance 15-06-2018, Published 25-06-2018.

Corresponding Author:

Dr. Sumanth Tarikere Parameshwaraiah,

Assistant Professor,

Department of Psychiatry,

Rajarajeshwari Medical College and Hospital,

Bangalore,

Karnataka, India

E-mail: sumanth_tp@yahoo.com

DOI: $10.14260 /$ jemds $/ 2018 / 673$ is the most frequently performed gynaecological operation worldwide. ${ }^{4,5}$

The symbolic meaning of uterus in women's psychological health is well known. Historically, physical displacement of uterus throughout the body was thought to cause various psychological symptoms in women.

Quality of Life (QOL) is the general well-being of individual in the society, outlining negative and positive features of life. It includes life satisfaction in domains of physical health, familial life, education, work, religious beliefs, finance and with one's environment [Table 1]. ${ }^{4}$

Sexual satisfaction is a broad construct closely linked to overall satisfaction in relationship. Sexual satisfaction is positively associated with indicators of quality of relationship such as love, commitment and stability, and is inversely related to likelihood of divorce.6-9

The current literature does not give a conclusive picture about the effect of hysterectomy on QOL, sexual satisfaction and psychiatric morbidities. The current study aims to 
evaluate the quality of life, sexual satisfaction and psychiatric morbidity in women who have been posted for hysterectomy.

\section{MATERIALS AND METHODS}

The study was conducted in a tertiary care hospital, by the Department of Psychiatry, in liaison with Obstetrics and Gynaecology department in Rajarajeshwari Medical College and Hospital, Bangalore. A cross-sectional study was conducted on women who were posted for hysterectomy over a period of three months. A sample size of 30 was taken for convenience to the study. Thirty subjects between age group of 18 and 50 years were included for the study. Subjects who were on Hormonal Replacement Therapy [HRT] with malignancy and who had attained menopause were excluded from the study. Written informed consent was obtained from all the participants who enrolled in the study. The study was approved by Institutional Review Committee and ethical clearance was obtained.

The socio-demographic details of these women were gathered using a semi-structured proforma, developed by the Department of Psychiatry [Table 3] and the subjects were assessed prior to surgery using World Health Organisation Quality of Life- BREF [WHOQOL-BREF] [Table 1].4 Sexual satisfaction was evaluated using sexual satisfaction scale for women [SSS-W] [Table 2].10 Clinical version of Structured Clinical Interview DSM-IV [SCID-I $]^{5}$ was used to determine the psychiatric co-morbidity.

\section{Statistical Analysis}

All statistical analysis was carried out using SPSS 16.0 software. Parameters were assessed using correlation coefficient and Mann-Whitney $U$ test and the $p$-value of $<0.05$ was considered significant.

\section{RESULTS}

Majority of the subjects were in the age group of 41 - 45 yrs. $90 \%$ of the subjects were Hindus, $86.7 \%$ were married, $43.3 \%$ were illiterates and $56.7 \%$ were housewives [Table 3].

More than half $(56.6 \%)$ of the subjects were suffering from psychiatric illnesses, among which fifty percent had mood disorders and six percent had anxiety disorders.

There was a significant difference between literates and illiterates in domain 2 QOL with p-value < 0.05 [Table 4]. Also significant difference for subjects with family income of $>$ Rs. $10,000 /$ month in domain 2 and domain 4 with p-value $<0.05$ was noted [Table 5].

The study also showed environmental factors (Domain 4) had significant effect on prevalence of psychiatric comorbidity among subjects [Table 6].

Sexual compatibility differences had significant effect on social relationships (Domain 3) and prevalence of psychiatric morbidity [Table 7 and 8].

Subjects who had low income and who were literates showed statistically significant psychological problems (Domain 2) [Table 4 and 5] and those with low income also had statistically significant low score in domain 4 (Environment factors).

\begin{tabular}{|c|c|}
\hline 1. Physical health & $\begin{array}{c}\text { Activities of daily living } \\
\text { Dependence on medicinal substances } \\
\text { and medical aids } \\
\text { Energy and fatigue } \\
\text { Mobility } \\
\text { Pain and discomfort } \\
\text { Sleep and rest } \\
\text { Work capacity }\end{array}$ \\
\hline 2. Psychological & \begin{tabular}{|c|} 
Bodily image and appearance \\
Negative feelings \\
Positive feelings \\
Self esteem \\
Spirituality/ Religion/ Personal beliefs \\
Thinking, learning, memory and \\
concentration \\
\end{tabular} \\
\hline $\begin{array}{l}\text { 3. Social } \\
\text { relationships }\end{array}$ & $\begin{array}{c}\text { Personal relationships } \\
\text { Social support } \\
\text { Sexual activity } \\
\end{array}$ \\
\hline 4. Environment & $\begin{array}{c}\text { Financial resources } \\
\text { Freedom, physical safety and security } \\
\text { Health and social care: accessibility } \\
\text { and quality } \\
\text { Home environment } \\
\text { Opportunities for acquiring new } \\
\text { information and skills } \\
\text { Participation in and opportunities for } \\
\text { recreation/ leisure activities } \\
\text { Physical environment } \\
\text { [pollution/noise/ } \\
\text { traffic/climate] Transport } \\
\end{array}$ \\
\hline
\end{tabular}

\begin{tabular}{|c|c|}
\hline Domains & $\begin{array}{c}\text { Contentment with emotional and sexual } \\
\text { aspects of the relationship }\end{array}$ \\
\hline Communication & $\begin{array}{c}\text { Ease and comfort discussing sexual and } \\
\text { emotional issues }\end{array}$ \\
\hline Compatibility & $\begin{array}{c}\text { Compatibility between partners in terms } \\
\text { of sexual beliefs, preferences, desires and } \\
\text { attraction }\end{array}$ \\
\hline Relational concern & $\begin{array}{c}\text { Distress regarding the impact of their } \\
\text { sexual problems on their partner and } \\
\text { relationship at large }\end{array}$ \\
\hline Personal concern & $\begin{array}{c}\text { Personal distress concerning sexual } \\
\text { problems }\end{array}$ \\
\hline \multicolumn{2}{|c|}{ Table 2. Sexual Satisfaction Scale for Women (SSS-W) } \\
\hline
\end{tabular}

\begin{tabular}{|c|c|c|c|}
\hline \multicolumn{3}{|c|}{ Socio-Demographic Variables } & \multirow{2}{*}{$\begin{array}{c}\text { Percentage } \\
3.3 \%\end{array}$} \\
\hline \multirow{3}{*}{1.} & \multirow{3}{*}{ Religion } & Christian & \\
\hline & & Hindu & $90 \%$ \\
\hline & & Muslim & $6.7 \%$ \\
\hline \multirow{4}{*}{2.} & \multirow{4}{*}{ Education } & Higher & $23.3 \%$ \\
\hline & & PUC & $3.3 \%$ \\
\hline & & Primary & $30.3 \%$ \\
\hline & & Illiterate & $43.3 \%$ \\
\hline \multirow{3}{*}{3.} & \multirow{3}{*}{ Occupation } & Employed & $36.7 \%$ \\
\hline & & Housewives & $56.7 \%$ \\
\hline & & Others & $6.7 \%$ \\
\hline \multirow{3}{*}{4.} & \multirow{3}{*}{ Marital Status } & Married & $86.7 \%$ \\
\hline & & Single & $3.3 \%$ \\
\hline & & Widow & $10.0 \%$ \\
\hline \multirow{2}{*}{5.} & \multirow{2}{*}{ Family Income } & $\begin{array}{l}<10,000 \\
\text { Rs./mnth }\end{array}$ & $80 \%$ \\
\hline & & $\begin{array}{l}>10,000 \\
\text { Rs./mnth }\end{array}$ & $20 \%$ \\
\hline & & able 3 & \\
\hline
\end{tabular}




\begin{tabular}{|c|c|c|c|c|c|}
\hline Domains & Education & Median & $\begin{array}{c}\text { Inter- } \\
\text { quartile } \\
\text { Range }\end{array}$ & $\begin{array}{c}\text { Mann- } \\
\text { Whitney U U }\end{array}$ & $\begin{array}{c}\text { P } \\
\text { value }\end{array}$ \\
\hline Domain 1 & $\begin{array}{c}\text { Illiterate } \\
\text { Literate }\end{array}$ & $\begin{array}{l}13.00 \\
14.00\end{array}$ & $\begin{array}{c}11.00-14.00 \\
13.00-14.00\end{array}$ & 81.500 & 0.205 \\
\hline Domain 2 & $\begin{array}{l}\text { Illiterate } \\
\text { Literate }\end{array}$ & 11.00 & $11.00-13.00$ & 61.000 & 0.033 \\
\hline Domain 3 & Illiterate & 14.00 & $11.00-14.00$ & & 0.76 .00 \\
& Literate & 15.00 & $14.00-16.00$ & 103.000 & 0.745 \\
\hline \multirow{2}{*}{ Domain 4 } & Illiterate & 11.00 & $9.00-13.5$ & 70.500 & 0.089 \\
& Literate & 12.50 & $11.5-14.5$ & & \\
\hline \multicolumn{7}{|c|}{ Table 4 } \\
\hline
\end{tabular}

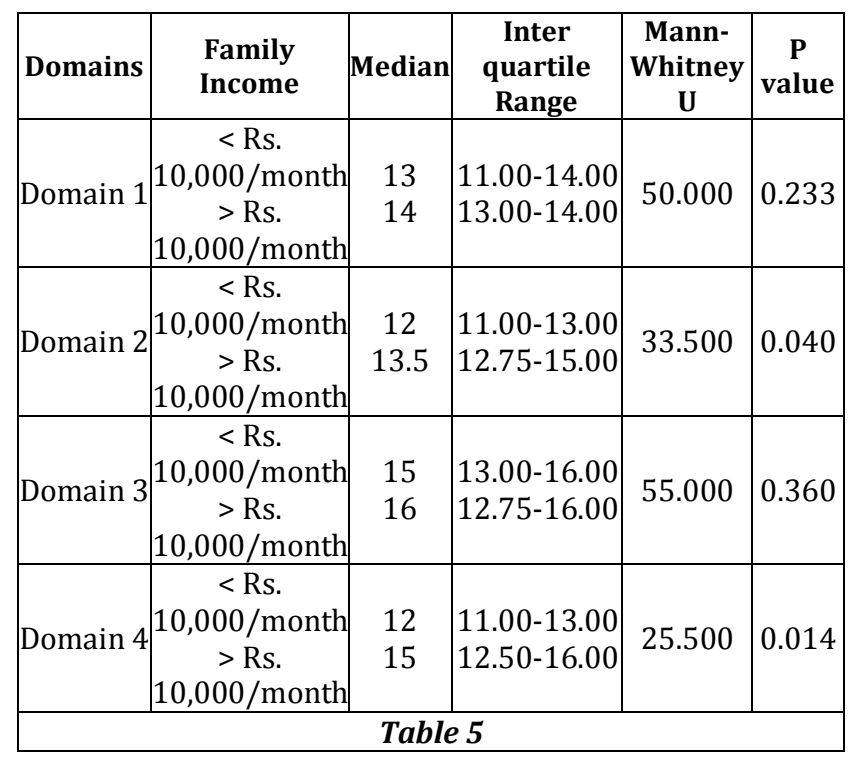

\begin{tabular}{|c|c|c|c|c|c|}
\hline Domains & $\begin{array}{l}\text { Psychiatric } \\
\text { Comorbidity }\end{array}$ & Median & $\begin{array}{c}\text { Inter } \\
\text { quartile } \\
\text { Range }\end{array}$ & $\begin{array}{c}\text { Mann- } \\
\text { Whitney } \\
\text { U }\end{array}$ & $\begin{array}{c}P \\
\text { value }\end{array}$ \\
\hline $\begin{array}{c}\text { Domain } \\
1\end{array}$ & $\begin{array}{c}\text { Present } \\
\text { Absent }\end{array}$ & $\begin{array}{l}13.00 \\
14.00\end{array}$ & $\begin{array}{l}11.00-14.00 \\
13.00-14.00\end{array}$ & 80.500 & 0.171 \\
\hline $\begin{array}{c}\text { Domain } \\
2 \\
\end{array}$ & $\begin{array}{l}\text { Present } \\
\text { Absent }\end{array}$ & $\begin{array}{l}13.00 \\
13.00\end{array}$ & $\begin{array}{l}11.00-13.50 \\
11.50-13.50\end{array}$ & 105.000 & 0.781 \\
\hline $\begin{array}{c}\text { Domain } \\
3 \\
\end{array}$ & $\begin{array}{l}\text { Present } \\
\text { Absent }\end{array}$ & $\begin{array}{l}15.00 \\
16.00 \\
\end{array}$ & \begin{tabular}{|l|}
$12.00-16.00$ \\
$15.00-16.00$ \\
\end{tabular} & 77.000 & 0.131 \\
\hline $\begin{array}{c}\text { Domain } \\
4\end{array}$ & $\begin{array}{c}\text { Present } \\
\text { Absent }\end{array}$ & $\begin{array}{l}11.00 \\
13.00\end{array}$ & $\begin{array}{l}10.00-12.50 \\
12.00-14.50\end{array}$ & 65.000 & 0.047 \\
\hline \multicolumn{6}{|c|}{ Table 6} \\
\hline
\end{tabular}

\begin{tabular}{|c|c|c|c|}
\hline \multirow{2}{*}{ SSS-W } & $\begin{array}{c}\text { Psychiatric } \\
\text { Co-morbidity }\end{array}$ & Mean & \multirow{2}{*}{ P value } \\
\hline \multirow{2}{*}{ Contentment } & Present & 20.87 & \multirow{2}{*}{0.339} \\
\cline { 2 - 3 } & Absent & 21.07 & \\
\hline \multirow{2}{*}{ Communication } & Present & 17.00 & \multirow{2}{*}{0.725} \\
\cline { 2 - 3 } & Absent & 17.21 & \\
\hline \multirow{2}{*}{ Compatibility } & Present & 22.33 & \multirow{2}{*}{0.041} \\
\cline { 2 - 3 } & Absent & 26.93 & \\
\hline \multirow{2}{*}{ Concern Relational } & Present & 27.40 & \multirow{2}{*}{0.406} \\
\cline { 2 - 3 } & Absent & 29.00 & \\
\hline \multirow{2}{*}{ Concern Personal } & Present & 26.73 & \multirow{2}{*}{0.405} \\
\cline { 2 - 3 } & Absent & 28.71 & \\
\hline \multicolumn{3}{|c|}{ Table 7 } \\
\hline
\end{tabular}

\begin{tabular}{|c|c|c|c|c|c|c|}
\hline$\overline{8}$ & & 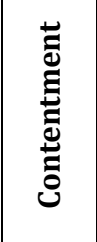 & 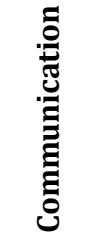 & 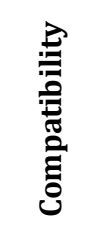 & 宽 & 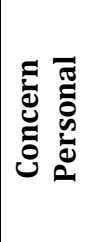 \\
\hline \multirow{2}{*}{$\begin{array}{c}\text { Domain } \\
1\end{array}$} & $\begin{array}{c}\text { Correlation } \\
\text { coefficient }\end{array}$ & 0.030 & 0.039 & 0.246 & 0.076 & 0.075 \\
\hline & $\begin{array}{c}\text { Sig. } \\
\text { (2-tailed) }\end{array}$ & 0.875 & 0.839 & 0.190 & 0.689 & 0.693 \\
\hline \multirow{2}{*}{$\begin{array}{c}\text { Domain } \\
2\end{array}$} & $\begin{array}{c}\text { Correlation } \\
\text { coefficient }\end{array}$ & 0.209 & 0.249 & -0.054 & -0.115 & 0.016 \\
\hline & $\begin{array}{c}\text { Sig. } \\
\text { (2-tailed) }\end{array}$ & 0.268 & 0.185 & 0.776 & 0.545 & 0.935 \\
\hline \multirow{2}{*}{$\begin{array}{c}\text { Domain } \\
3\end{array}$} & $\begin{array}{c}\text { Correlation } \\
\text { coefficient }\end{array}$ & -0.048 & 0.183 & -0.383 & 0.194 & 0.147 \\
\hline & $\begin{array}{c}\text { Sig. } \\
\text { (2-tailed) }\end{array}$ & 0.803 & 0.332 & 0.037 & 0.304 & 0.440 \\
\hline \multirow{2}{*}{$\begin{array}{c}\text { Domain } \\
4\end{array}$} & $\begin{array}{c}\text { Correlation } \\
\text { coefficient }\end{array}$ & 0.076 & 0.080 & 0.252 & -0.065 & 0.009 \\
\hline & $\begin{array}{c}\text { Sig. } \\
\text { (2-tailed) }\end{array}$ & 0.689 & 0.674 & 0.180 & 0.732 & 0.366 \\
\hline
\end{tabular}

\section{psychiatric co-morbidty among patient posted for hysterectomy}

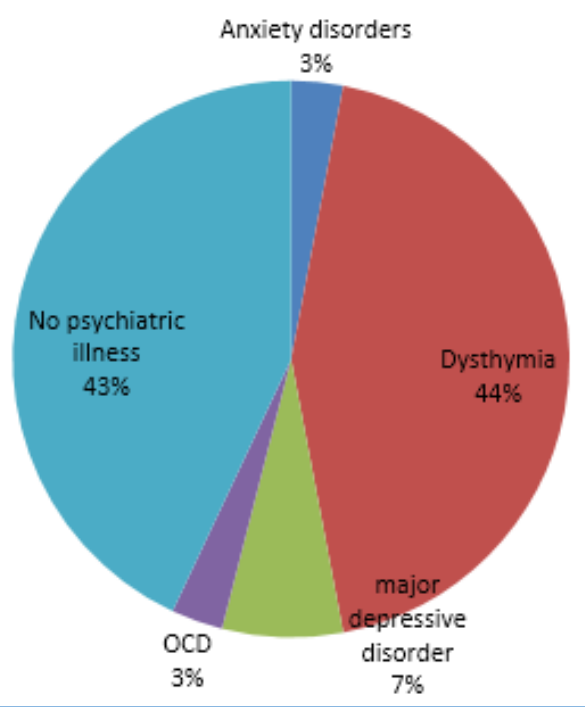

Figure 1

\section{DISCUSSION}

Hysterectomies are one of the most common major surgeries performed in the world. Around $90 \%$ of all hysterectomies are carried out for benign conditions ${ }^{11}$ with the commonest indications being uterine fibroid, dysfunctional uterine bleeding, endometriosis, vaginal prolapse and chronic pelvic pain. ${ }^{12}$

A higher frequency of hysterectomy is seen in the Western countries $(10-20 \%), 13$ while lower rate has been reported from India (4-6\%). ${ }^{14-17}$

Surgical removal of the uterus and frequently even the ovaries is widely accepted both by medical professionals and the public, as appropriate treatment for various common non-cancerous uterine conditions that can produce often severe pain, discomfort, uterine bleeding and psychological 
distress. The current study was done with a view to derive the socio-demographic profile, psychiatric morbidity and quality of life among women who were posted for hysterectomy.

Most of the Western studies report that hysterectomy has a negative influence on women, as they feel that the uterus is a very important organ and losing it would reduce their selfrespect and self-confidence. They were also worried about their body image, sexual lives and relationships. Women in the West also had a notion that they would not feel like a woman and it would affect their social functions [QOL Domain 2, 4].11,18,19 This was in accordance with the current study where there was a worry about the body image, reduction of self-esteem and relationship issues mostly with literate women with a family income of $<$ Rs. 10,000/month.

Indian studies also supported the present study where women expressed fears about possible change in body image, sexual dysfunction and discomfort [QOL Domain 2].20-23

Permanent surgical procedure like hysterectomy will invariably influence the sexual functioning of the women who are subjected to it. Indian as well as Western studies report that removal of uterus would result in sexual dysfunction, low self-confidence and the belief that their spouses would not be interested in them anymore, which leads to interpersonal problems, impaired body image and reduction in quality of life, $11,18,19$ which is in accordance with the present study.

Seventeen out of 30 subjects (56.6\%) who were posted for surgery were suffering from mood disorders, among which (43.3\%) and 6.7\% had dysthymia and major depressive disorder respectively. The high prevalence of mood disorders was similar to earlier studies. ${ }^{20,24-27}$ However, the prevalence of anxiety disorders in our study was only $6.6 \%$, which is much lower than the others studies.28-30

\section{CONCLUSION}

It was found that there was a higher prevalence of psychiatric co-morbidity, mostly mood and anxiety disorders in women who are undergoing hysterectomy. There was a decrease in sexual satisfaction and quality of life in the preoperative period. Awareness on the part of surgeons and other medical professionals for certain pre-existing psychological and psychosocial problems in the pre-operative period would enable timely reference of high risk women for psychiatric consultation and intervention. There were a few limitations for the present study, as it was carried on a limited sample size and hence the results could not be generalised to a larger population.

\section{REFERENCES}

[1] Domingo S, Pellicer A. Overview of current trends in hysterectomy: five-year view. Expert Rev Obstet Gynecol 2009;4(6):673-85.

[2] Nieboer TE, Johnson N, Lethaby A, et al. Surgical approach to hysterectomy for benign gynaecological disease. Cochrane Database Syst Rev 2009;(3):CD003677.
[3] Einarsson JI, Matteson KA, Schulkin J, et al. Minimally invasive hysterectomies-a survey on attitudes and barriers among practicing gynecologists. J Minim Invasive Gynecol 2010;17(2):167-75.

[4] Szabo S. The World Health Organisation Quality of Life (WHOQOL) assessment instrument. In: Spilker B, edr. Quality of life and pharmaeconomics in clinical trials. $2^{\text {nd }}$ edn. Philadelphia: Lippincott-Raven 1996.

[5] First MB, Spitzer RL, Gibbon M, et al. Structured clinical interview for DSM-IV-TR Axis I disorders, Research version, Patient edition with psychotic screen (SCID-I/P W/ PSY SCREEN) New York: Biometrics Research, New York State Psychiatric Institute, November 2002.

[6] Blumstein P, Schwartz P. American couples. 1st edn. New York: William Morrow \& Company, Inc., 1983.

[7] Edwards JN, Booth A. Sexuality, marriage and wellbeing: the middle years. In: Rossi AA, edr. Sexuality across the life course. Chicago: University of Chicago Press 1994: p. 233-59.

[8] Yela C. Predictors of and factors related to loving and sexual satisfaction for men and women. Eur Rev Appl Psyc 2000;50:235-43.

[9] Sprecher S. Sexual satisfaction in premarital relationships: associations with satisfaction, love, commitment and stability. J Sex Res 2002;39(3):190-6.

[10] Meston C, Trapnell P. Development and validation of a five-factor sexual satisfaction and distress scale for women: The Sexual Satisfaction Scale for Women (SSSW). J Sex Med 2005;2(1):66-81.

[11] Jawor M, Dimter A, Marek K, et al. Anxiety-depressive disorder in women after hysterectomy. Own Study. Psychiatr Pol 2001;35(5):771-80.

[12] Farquhar CM, Steiner CA. Hysterectomy rates in the United States 1990-1997. Obstet Gynecol 2002;99(2):229-34.

[13] Kaur S. Profile of women in early postmenopausal age in suburban Chandigarh. Ph.D Thesis (unpublished) PGIMER, Chandigarh, India, 2001.

[14] Kumari S, Walia I, Singh A. Self-reported uterine prolapse in a resettlement colony of north India. J Midwifery Womens Health 2000;45(4):343-50.

[15] Singh AJ, Arora AK. Menopausal women's profile in rural north India - an integrated qualitative and quantitative study. Adv Obstet Gynecol 2000;52:30913.

[16] Singh AJ, Arora AK. Effect of uterine prolapse on the lives of rural north Indian Women. Singapore J Obstet Gynecol 2003;34:52-8.

[17] Singh A, Arora AK. Profile of menopausal women in rural north India. Climacteric 2005;8(2):177-84.

[18] Reis N, Engin R, Ingec $M$, et al. A qualitative study: beliefs and attitudes of women undergoing abdominal hysterectomy in Turkey. International Journal of Gynecologic Cancer 2008;18(5):921-8.

[19] Flory N, Bissonnette F, Binik YM. Psychosocial effects of hysterectomy: literature review. J Psychosom Res 2005;59(3):117-29.

[20] Yen JY, Chen YH, Long CY, et al. Risk factors for major depressive disorder and the psychological impact of hysterectomy: a prospective investigation. Psychosomatics 2008;49(2):137-42. 
[21] Kincey J, McFarlane T. Psychological aspects of hysterectomy. In: Broome A, Wallace L, eds. Psychology and Gynaecological problems. London: Tavistock Publications 1984: p. 142-60.

[22] Lalinec-Michaud M, Engelsmann F. Anxiety, fears and depression related to hysterectomy. Can J Psychiatry 1985;30(1):44-7.

[23] Farooqi YN. Depression and anxiety in patients undergoing hysterectomy. Journal of Pakistan Psych Society 2005;2(1):13-6.

[24] Subramaniam D, Subramaniam SK, Charles SX, et al. Psychiatric aspects of hysterectomy. Indian J Psychiatry 1982;24(1):75-9.

[25] Donoghue AP, Jackson HJ, Pagano R. Understanding pre-and post-hysterectomy levels of negative affect: a stress moderation model approach. J Psychosom Obstet Gynaecol 2003;24(2):99-109.
[26] Ozdemir F, Pasinlioglu T. The effects of training and progressive relaxation exercises on anxiety level after hysterectomy. The New Journal of Medicine. 2009;26:102-7.

[27] Helmy YA, Hassanin IM, Elraheem TA, et al. Psychiatric morbidity following hysterectomy in Egypt. Int J Gynaecol Obstet 2008;102(1):60-4.

[28] Kjerulff KH, Langenberg PW, Rhodes JC, et al. Effectiveness of hysterectomy. Obstet Gynecol 2000;95(3):319-26.

[29] Montazeri A, Vahdaninia M, Ebrahimi M, et al. The Hospital Anxiety and Depression Scale (HADS): translation and validation study of the Iranian version. Health and Quality of Life Outcomes 2003;1:14.

[30] Chynoweth R. Psychological complications of hysterectomy. Aust N Z J Psychiatry 1973;7(2):102-4. 